INTERNATIONAL JOURNAL OF MULTIDISCIPLINARY RESEARCH AND ANALYSIS

ISSN(print): 2643-9840, ISSN(online): 2643-9875

Volume 05 Issue 01 January 2022

DOI: 10.47191/ijmra/v5-i1-04, Impact Factor: 6.072

Page No.- 24-31

\title{
The Effect of Capital Adequacy Rasio (CAR) and Liquidity on Profitability of Islamic Comercial Banks in Indonesia for The 2015- 2019 Period
}

\author{
DedyDwi Arseto ${ }^{1}$, Sabaruddun Chaniago ${ }^{2}$, Andri Soemitra ${ }^{3}$, IskandarMuda ${ }^{4}$, Sugianto ${ }^{5}$ \\ 1,2,3,4,5 North Sumatra State Islamic University, Medan, Indonesia
}

ABSTRACT: This study aims to determine how the Effect of Capital Adequacy Ratio (CAR) and Liquidity on Profitability of Islamic Commercial Banks in Indonesia for the 2015-2019 Period. The results of data processing using the SPSS 17 For Windows program resulted in multiple regression analysis with two independent variables and one dependent variable showing that $Y=1.108$ $+1.404 \times 1-0.240$ X2, meaning that profitability is influenced by Capital Adequacy Ratio (CAR) and Liquidity. Furthermore, the results show that the Capital Adequacy Ratio (CAR) and Liquidity variables can explain the Profitability variable $36 \%$, the remaining $64 \%$ is explained by other variables. The results of the hypothesis test state that: Hypothesis 1 is accepted, this can be seen from the value of tcount>ttable, then the Capital Adequacy Ratio (CAR) has an effect on profitability. The second hypothesis is rejected, it can be seen from the value of tcount<ttable, it is stated partially that Liquidity has no effect on Profitability. Hypothesis 3 is accepted, it can be seen from the value of Fcount>Ftable, it is stated simultaneously that Capital Adequacy Ratio (CAR) and Liquidity have an effect on Profitability.

KEYWORDS: Capital Adequacy Ratio (CAR) and Liquidity, Profitability

\section{INTRODUCTION}

Indonesia is one of the countries with the largest Muslim majority population in the world, indirectly this shows a huge potential for sharia sector economic activities in Indonesia. Public awareness of Islamic law will determine the amount of growth of Islamic economic activity in Indonesia. The Islamic banking sector is the sector that is most positively affected by the increasing public awareness of Islamic law, this is because every community activity is currently not separated from banking, either as a place to store funds that have been obtained or obtain funds as capital to run a business. In general, banks have the function of collecting and distributing public funds, so banks are also referred to as agents of public trust. According to Hasibuan (2015: 4), apart from functioning as an agent of trust, banks also function for national economic development (agent of development) in order to increase income distribution, economic growth, and national stability.

The presence of Islamic banking was initially triggered by the desire of Muslims for financial services based on sharia principles which were expected to avoid the practice of usury, maysir, gharar and other practices that were considered incompatible with Islamic principles. According to Adiwarman (2010: 25) in 1992 the first Islamic banking industry in Indonesia was established, namely Bank Muamalat Indonesia (BMI). Although the development is late when compared to other Muslim countries, in 1992-1998 there was only one Sharia Bank unit, in 2005 the number of Sharia Banks in Indonesia had increased to 20 units, namely 3 Sharia Commercial Banks and 17 Sharia Business Units. In the last few years, Indonesia has experienced very rapid growth in Islamic finance. By the end of 2019, there were 14 sharia commercial banks, 20 sharia business units and 164 sharia people's financing banks with total assets of Rp. 538.32 trillion, while the third party funds that can be collected is Rp. 425.29 trillion and distributed Rp. 365.13 trillion. On October 17, 2019, Indonesia managed to rank first in the Islamic finance market in the Islamic Finance Country Index (IFCl) 2019 from 48 countries. The growth of sharia banking is very rapid, but it is common for every bank to have differences in its management in terms of finances, which can be presented in the following figure: 
The Effect of Capital Adequacy Rasio (Car) and Liquidity on Profitability of Islamic Comercial Banks in Indonesia for The 2015-2019 Period

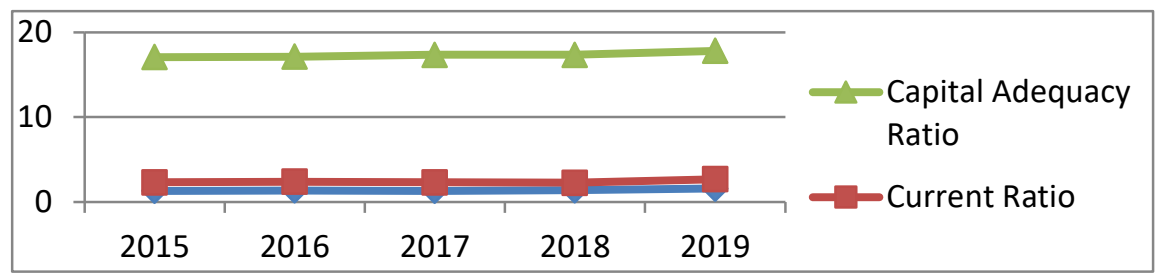

Figure 1. Average Annual Return on Assets, Capital Adequacy Ratio and Current Ratio of Islamic Banking Companies in Indonesia 2015 - 2019

Figure 1 illustrates the profit, ability to pay debts, and the capital adequacy ratio of Islamic banking in Indonesia as seen from the Return On Assets, Current Ratio and Capital Adequacy Ratio. In the data there are differences in theory with facts, where the decline in profitability in the last 1 year on average per year, namely in 2017 experienced by Islamic commercial bank companies, but the Capital Adequacy Ratio in 2017 has increased from the previous year 2016. of $0.31 \%$, as well as the Current Ratio only decreased by $0.02 \%$ in the same year. In previous research, there are differences in the results of research conducted by SyifaMutiaulfah (2018) entitled The Effect of Current Ratio (CR) and Capital Adequacy Ratio (CAR) on Return On Assets (ROA) at Bank BNI SyariahTbk, with the results of Current Ratio (CR) and Capital Adequacy Ratio (CAR) has an effect on Return On Assets (ROA). While the research conducted by Herman Supardi (2016) entitled The Effect of Current Ratio, Debt To Asset Ratio, Total Asset Turnover and Inflation on Return On Assets, with the results of the Current Ratio having no effect on Return On Assets, and research conducted by Dwi Indah (2016) entitled The Effect of Non-Performing Loans (NPL) and Capital Adequacy Ratio (CAR) on Profitability in Banking Companies Listed on the IDX with the result that the Capital Adequacy Ratio has no effect on Return On Assets.

Based on the facts and research gaps that were stated previously, it attracted attention to conduct a study entitled "The Effect of Capital Adequacy Ratio (CAR) and Liquidity on Profitability of Islamic Commercial Banks in Indonesia for the 2015-2019 Period".

\section{LITERATURE REVIEW}

\section{Profitability}

According to Kasmir (2011: 196) states that the profitability ratio is a ratio to assess the company's ability to seek profit in providing a measure of the effectiveness of the company's management, this is indicated by the profits earned and investment income. In other words, profitability is the company's ability to generate profits. According to Home and Wachowiz in Satriana (2017:12), profit is also often compared to other financial conditions such as sales, assets and equity. This comparison is called the profitability ratio. According to Kasmir (2011: 196) states that the profitability ratio is a ratio to assess the company's ability to seek profit in providing a measure of the effectiveness of the company's management, this is indicated by the profits earned and investment income. According to Brigham and Houston in Satriana (2017:15) stated that ROA can be calculated as the following formula:

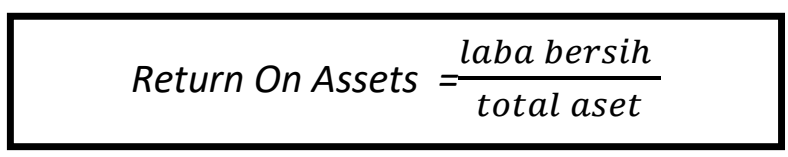

\section{Capital Adequacy Ratio (CAR)}

According to Mia Lasmi (2013: 295) Capital Adequacy Ratio (CAR) is the ratio of the bank's capital adequacy or the ability of the bank in existing capital to cover possible losses in credit or securities trading. Meanwhile, according to Dendawijaya (2012: 120) Capital Adequacy Ratio (CAR) is a ratio that shows how far all bank assets that contain risks (credit, investments, securities, claims on other banks) are also financed from the bank's own capital funds in addition to obtaining funds from sources outside the bank, such as public funds, loans (debt), and others. In other words, the Capital Adequacy Ratio is a bank's performance ratio to measure the adequacy of capital owned by a bank to support assets that contain or generate risks, such as loans. According to Mia Lasmi (2013: 295) the ratio of the Capital Adequacy Ratio can be formulated as follows:

\section{Bank Capital}

$C A R=$ $\times 100 \%$

Risk Weighted Assets 
The Effect of Capital Adequacy Rasio (Car) and Liquidity on Profitability of Islamic Comercial Banks in Indonesia for The 2015-2019 Period

\section{Liquidity}

According to Subramanyam and Wild (2010:241), liquidity refers to the company's ability to meet its short-term obligations. Meanwhile, according to Munawir in Satriana (2017: 18) revealed that liquidity shows the company's ability to meet financial obligations that must be fulfilled immediately or the company's ability to meet financial obligations when billed. According to Fahmi (2013:157-158) if a company experiences problems in liquidity, it is very possible for the company to enter a period of financial difficulty and if not above, it will lead to business bankruptcy. Henry (2015:175) states that the liquidity ratio is a ratio that shows the company's ability to meet obligations or pay short debts. The formula to find the current ratio is as follows:

\section{Current Rasio $=$ Total AktivaLancar $/$ Total Kewajiban}

\section{Framework of thinking}

Based on the gap research found previously, the conceptual framework model can be seen as follows:

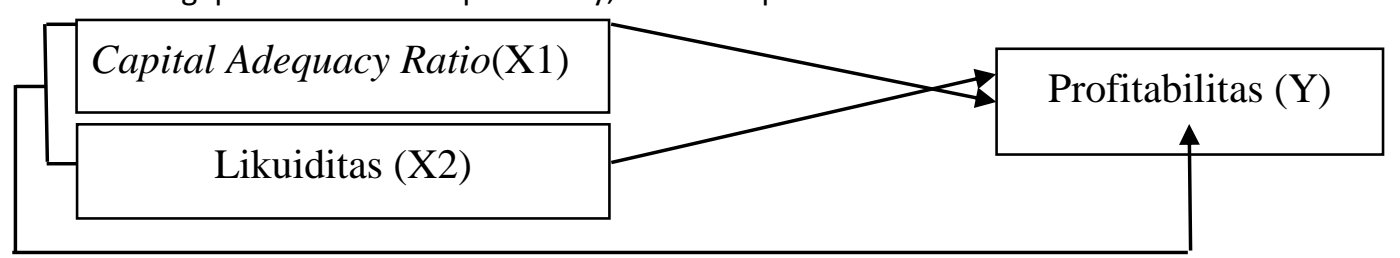

Figure 2. Conceptual Framework

\section{Hypothesis}

Based on Figure 2, the research hypothesis can be formulated as follows:

H1 : Capital Adequacy Ratio (CAR) has an effect on Profitability of Islamic Commercial Banks in Indonesia for the 2015-2019 Period

H2: Liquidity (CR) has an effect on Profitability (ROA) at Islamic Commercial Banks in Indonesia for the 2015-2019 period.

H3 : Capital Adequacy Ratio (CAR) and Liquidity have a simultaneous effect on Profitability (ROA) at Islamic Commercial Banks in Indonesia for the 2015-2019 Period.

\section{RESEARCH METHODS}

\section{Population and Sample}

In this study, the population used were Islamic commercial bank companies registered with the Financial Services Authority as many as 14 companies. The sampling technique is using purposive sampling, where the sample is taken through certain considerations whose criteria are determined by the researcher himself. The criteria set by the researchers are:

1. Sharia banking company registered with the Financial Services Authority in 2015-2019.

2. Islamic banking companies that publish complete financial reports for 2015-2019.

3. Banking companies that consistently generate profits in 2015-2019.

Based on these criteria, the number of samples in the study were 8 companies, with a research year of 5 years starting from 2015-2019. The following is a list of Food and Beverage companies according to the research criteria listed on the Indonesia Stock Exchange.

Table 3.2.Company Sample

\begin{tabular}{|c|l|}
\hline No & Company name \\
\hline 1 & PT. Bank BCA Syariah \\
\hline 2 & PT. BNI Syariah Bank \\
\hline 3 & PT. Sharia National Pension Savings Bank \\
\hline 4 & PT. Bank MaybankSyariah Indonesia \\
\hline 5 & PT. Bank Muamalat Indonesia \\
\hline 6 & PT. Pain Bank Dubai Sharia \\
\hline 7 & PT. MandiriSyariah Bank \\
\hline 8 & PT. Victoria Sharia Bank \\
\hline
\end{tabular}


The Effect of Capital Adequacy Rasio (Car) and Liquidity on Profitability of Islamic Comercial Banks in Indonesia for The 2015-2019 Period

Data collection technique

Data collection techniques that will be used in this study are:

1. Literature study

This study is conducted by reading books or journals as a basis for analysis and formulation of theories or information related to research,

2. Documentation

This is done by looking at historical data, namely the 2015 to 2019 financial statements.

\section{Data analysis technique}

Multiple linear regression testing can be done after the model from this study meets the requirements, namely passing the classical assumptions. The conditions that must be fulfilled are that the data must be normally distributed, not containing multicollinearity, heteroscedasticity and autocorrelation.

\section{Hypothesis testing}

1. Significant test of individual parameters ( $t$ test)

The t-test is used to test the simultaneous effect of independent variables on the dependent variable. A variable of a variable will have a significant effect if the tcount value of the variable is greater than the ttable value.

The results of the hypothesis $t$ are compared with $t$ with the following test criteria:

a. If $\mathrm{t}$-count $>\mathrm{t}$-table at $5 \%$ then $\mathrm{Ho}$ is rejected and $\mathrm{H} 1$ is accepted (peruhnya).

b. If $\mathrm{t}$-count $<\mathrm{t}$-table at $5 \%$ then $\mathrm{Ho}$ is accepted and $\mathrm{H} 1$ is rejected (no effect).

2. Simultaneous Significant Test (F Test)

The $F$ test is used to see whether the independent variables together (simultaneously) have an influence on the dependent variable. Testing by comparing Fcount with Ftable with the following conditions:

a. If Fcount>Ftable at $5 \%$ then $\mathrm{Ho}$ is rejected and $\mathrm{Ha}$ is accepted (influential).

b. If Fcount $<$ Ftable at $5 \%$ then $\mathrm{Ho}$ is accepted and $\mathrm{Ha}$ is rejected (no effect).

\section{RESEARCH RESULT}

\section{Classic assumption test}

\section{Normality Test}

Normality test aims to test whether in the regression model, the confounding variable or residual has a normal distribution. The test results use SPSS 17 as follows:

Table 1. One Sample Kolmogorov Smirnov Test

One-Sample Kolmogorov-Smirnov Test

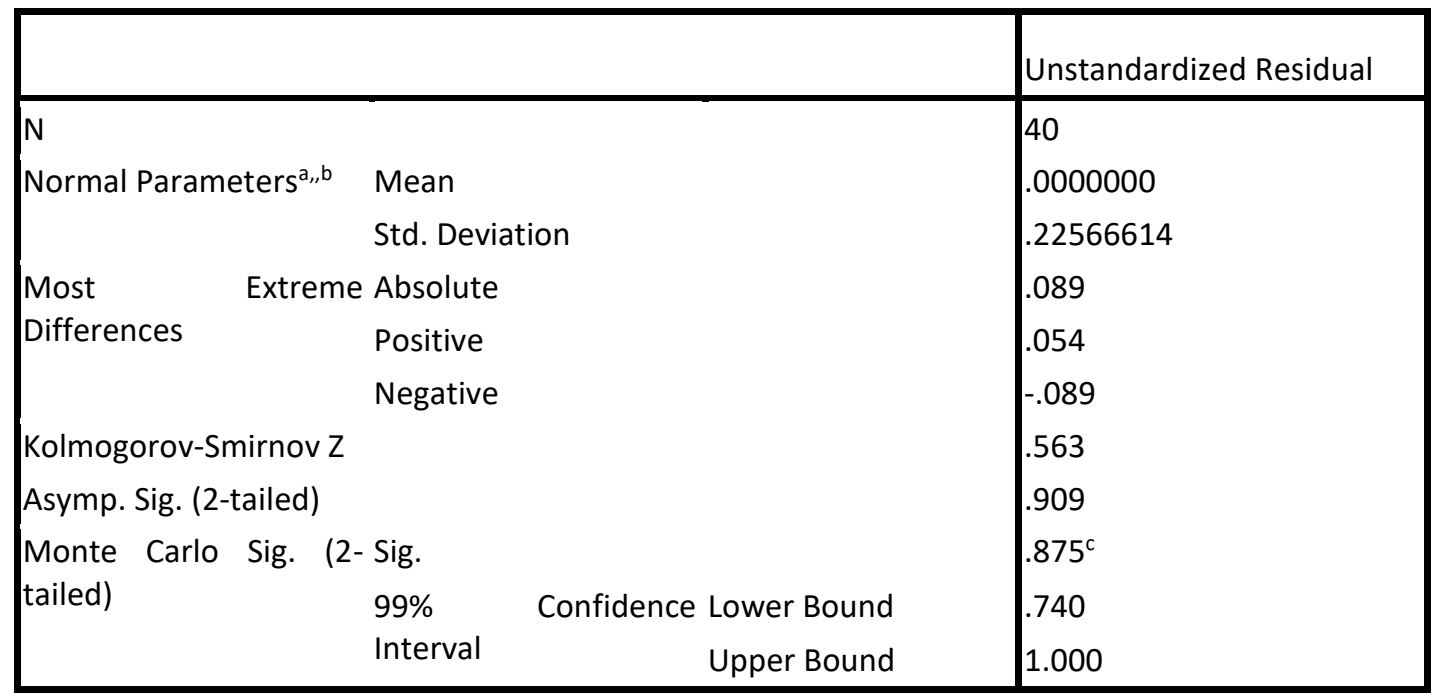

a. Test distribution is Normal.

b. Calculated from data.

c. Based on 40 sampled tables with starting seed 2000000.

Source: Data processed in 2021 
The Effect of Capital Adequacy Rasio (Car) and Liquidity on Profitability of Islamic Comercial Banks in Indonesia for The 2015-2019 Period

From the output in table 4.1, it can be seen that the significance value (Monte Carlo Sig.) of all variables is 0.875 . If the significance is more than 0.05 , then the residual value is normal, so it can be concluded that all variables are normally distributed.

\section{Multicollinearity Test}

The multicollinearity test aims to determine whether there is a correlation between the independent variables in the regression model. The multicollinearity test in this study is seen from the tolerance value or variance inflation factor (VIF). The calculation of the tolerance value or VIF with the SPSS 17.00 program for windows can be seen in Table 2 below:

\section{Table 2.Multicollinearity Test Results}

\begin{tabular}{|c|c|c|}
\hline \multicolumn{3}{|l|}{ Coefficients $^{\mathrm{a}}$} \\
\hline \multirow[b]{2}{*}{ Model } & \multicolumn{2}{|c|}{ Collinearity Statistics } \\
\hline & Tolerance & VIF \\
\hline $1 \quad$ (Constant) & & \\
\hline CAR & .609 & 1.643 \\
\hline $\mathrm{CR}$ & .609 & 1.643 \\
\hline
\end{tabular}

a. Dependent Variable: ROA

Source: Data processed in 2021

Based on table 2, it can be seen that the tolerance value of the Capital Adequacy Ratio (X1) variable is 0.609, Current Ratio (X2) variable is 0.609 , all of which are greater than 0.10 while the VIF value of the Capital Adequacy Ratio (X1) variable is 1.643 Current variable. Ratio (X2) is 1.643, all of which are smaller than 10. Based on the results of the above calculations, it can be seen that the tolerance value of all independent variables is greater than 0.10 and the VIF value of all independent variables is also smaller than 10 so that there is no correlation symptom in independent variable. So it can be concluded that there is no symptom of multicollinearity between independent variables in the regression model.

\section{Heteroscedasticity Test}

The heteroscedasticity test aims to test whether from the regression model there is an inequality of variance from the residuals of one observation to another observation. A good regression model is one with homoscedasticity or no heteroscedasticity. One way to detect the presence or absence of heteroscedasticity is the Glejser test, in the Glejser test, if the independent variable is statistically significant in influencing the dependent variable, then there is an indication of heteroscedasticity. The results of data processing using SPSS 17.00 show the results in the following table:

\section{Table 3.Glejser Test Results}

\section{Coefficients $^{\mathrm{a}}$}

\begin{tabular}{|l|l|l|l|l|l|}
\hline \multirow{2}{*}{ Model } & \multicolumn{2}{|l|}{ Unstandardized Coefficients } & Standardized Coefficients & & \\
\cline { 2 - 5 } & $\mathrm{B}$ & Std. Error & Beta & $\mathrm{t}$ & Sig. \\
\hline 1 (Constant) & .290 & .079 & & 3.679 & .001 \\
CAR & -.012 & .017 & -.148 & -.726 & .472 \\
CR & -.074 & .046 & -.331 & -1.631 & .111 \\
\hline
\end{tabular}

a. Dependent Variable: abs_res1

Source: Data processed in 2021

Based on table 3, the Sig Capital Adequacy Ratio is 0.193 and the Current Ratio is 0.802 , both of which are greater than 0.050 so it can be concluded that there are no symptoms of heteroscedasticity in this model. 
The Effect of Capital Adequacy Rasio (Car) and Liquidity on Profitability of Islamic Comercial Banks in Indonesia for The 2015-2019 Period

Autocorrelation Test

The autocorrelation test aims to test whether in the linear regression model there is a correlation between the confounding error in period $t$ and the confounding error in period t-1 (previous). Autocorrelation test using Durbin-Watson test, with criteria $\mathrm{du}<\mathrm{d}<4$-du. The test results using SPSS 17.00 in are shown as follows:

\section{Table 4.Autocorrelation Test}

Model Summary

\begin{tabular}{|c|c|c|c|c|c|c|c|c|c|c|}
\hline \multirow[b]{2}{*}{ Model } & \multirow[b]{2}{*}{$R$} & \multirow[b]{2}{*}{$\begin{array}{l}\mathrm{R} \\
\text { Square }\end{array}$} & \multirow[b]{2}{*}{ Adjusted R Square } & \multirow[b]{2}{*}{ Std. Error of the Estimate } & \multicolumn{5}{|l|}{ Change Statistics } & \multirow[b]{2}{*}{$\begin{array}{l}\text { Durbin- } \\
\text { Watson }\end{array}$} \\
\hline & & & & & R Square Change & F Change & df1 & df2 & $\mid \begin{array}{l}\text { Sig. F } \\
\text { Change }\end{array}$ & \\
\hline 1 & $.627^{\mathrm{a}}$ & .393 & .360 & .455322 & .393 & 49.482 & 2 & 37 & .000 & 1.806 \\
\hline
\end{tabular}

a. Predictors: (Constant), CR, CAR

b. Dependent Variable: ROA

Source: Data processed in 2021

From table 4, it can be seen that the Durbin Watson value is 1.806 while the Durbin Watson table value with $\mathrm{n}: 40$ and $\mathrm{k}: 3$ is 1.658. Because the Durbin Watson score is between 1.658 and $4-1.658$ (2.342), it can be concluded that there is no autocorrelation symptom.

\section{Hypothesis testing}

t test (Partial)

In this study, partial hypothesis testing was carried out on each independent variable as shown in Table 5 below:

Table 5. Partial Test $(t)$

\begin{tabular}{|c|c|c|c|c|c|}
\hline \multirow[b]{2}{*}{ Model } & \multicolumn{2}{|c|}{$\begin{array}{l}\text { Unstandardized } \\
\text { Coefficients }\end{array}$} & \multirow{2}{*}{\begin{tabular}{|l|}
$\begin{array}{l}\text { Standardized } \\
\text { Coefficients }\end{array}$ \\
Beta \\
\end{tabular}} & \multirow[b]{2}{*}{$\mathrm{t}$} & \multirow[b]{2}{*}{ Sig. } \\
\hline & B & Std. Error & & & \\
\hline 1 (Constant) & 1.108 & .890 & & 1.245 & .221 \\
\hline CAR & 1.404 & .188 & .820 & 7.460 & .000 \\
\hline$C R$ & -.240 & .516 & -.051 & -.466 & .644 \\
\hline
\end{tabular}

a. Dependent Variable: ROA

Source: Data processed in 2021

a. Hypothesis Testing the Effect of Capital Adequacy Ratio (X1) Variable on Return On Assets (Y)

From table 5 , the tcount value is 7.460 . With $=5 \%$, ttable $(5 \% ; n k=38)$ the ttable value is 2.024 . From the description it can be seen that tcount (7.460) >ttable (2.024), as well as the significance value of $0.000<0.05$, it can be concluded that the first hypothesis is accepted, meaning that the Capital Adequacy Ratio (X1) variable affects the Return On Asset (Y) variable. The results of this study are in line with the results of SyifaMutiaulfah's research (2018) with the title "The Effect of Current Ratio (CR) and Capital Adequacy Ratio (CAR) on Return On Assets (ROA) at Bank BNI SyariahTbk Period 2014-2016.

b. Hypothesis Testing the Effect of Variable Current Ratio (X2) on Variable Return On Assets .. (Y)

From table 5 , the tcount value is -0.466 . With $=5 \%$, ttable $(5 \%$; $n k=38)$ the ttable value is 2.024 . From the description it can be seen that tcount $(-0.466)<$ ttable (2.024), and the significance value is $0.644>0.05$, it can be concluded that the second hypothesis is rejected, meaning that the Current Ratio (X2) variable has no effect on the Return On Asset (Y) variable. The results of this study are in line with the research results of Herman Supardi, H. Suratno, Suyanto (2016) with the title "The Effect of Current Ratio, Debt To Asset Ratio, Total Asset Turnover and Inflation on Return On Assets". 
The Effect of Capital Adequacy Rasio (Car) and Liquidity on Profitability of Islamic Comercial Banks in Indonesia for The 2015-2019 Period

F Test (Simultaneous)

The results of the $\mathrm{F}$ test can be seen in table 6 below:

Table 6. Simultaneous Test Results (F)

ANOVA $^{b}$

\begin{tabular}{|l|l|l|l|l|l|}
\hline Model & Sum of Squares & df & Mean Square & F & Sig. \\
\hline 1 Regression & 202.088 & 2 & 101.044 & 49.482 & $.000^{a}$ \\
Residual & 75.555 & 37 & 2.042 & & \\
Total & 277.644 & 39 & & & \\
\hline
\end{tabular}

a. Predictors: (Constant), CR, CAR

b. Dependent Variable: ROA

Source: Data processed in 2021

From table 6, the Fcount value is 49.482 With $=5 \%$, dk numerator: 2 , dk denominator: nk-1 (5\%; 2:37) Ftable value is 3.25 . From the description it can be seen that Fcount (49.482) >Ftable (3.25), and a significance value of $0.000<0.05$, it can be concluded that the third hypothesis is accepted, meaning that the Capital Adequacy Ratio (X1) and Current Ratio (X2) variables have a simultaneous (simultaneous) effect on the Return variable. On Assets (Y) .

\section{CONCLUSION}

1. From this study shows that the ability of Capital Adequacy Ratio (CAR), Current Assets (CR) can Return on Assets (ROA) of 0.360 or $36 \%$. far close to the number 1 , so it can be said that the regression model used is not good.

2. The first hypothesis proposed states that the Capital Adequacy Ratio (CAR) has an effect on Profitability at Islamic Commercial Banks in Indonesia for the 2015-2019 Period. From the results of processing SPSS.17, it shows that the first hypothesis is accepted, meaning that the Capital Adequacy Ratio (CAR) has an effect on Profitability at Islamic Commercial Banks in Indonesia for the 2015-2019 period.

3. The second hypothesis proposed states that Liquidity has an effect on Profitability (ROA) in Islamic Commercial Banks in Indonesia for the 2015-2019 Period. From the results of SPSS.17 processing shows that the second hypothesis is accepted, meaning that Liquidity affects Profitability (ROA) in Islamic Commercial Banks in Indonesia. Indonesia for the 2015-2019 period.

4. The third hypothesis proposed states that the Capital Adequacy Ratio (CAR) and Liquidity have a simultaneous (simultaneous) effect on Profitability (ROA) at Islamic Commercial Banks in Indonesia for the 2015-2019 period. Adequacy Ratio (CAR) and Liquidity have a simultaneous effect on Profitability (ROA) at Islamic Commercial Banks in Indonesia for the 2015-2019 Period.

\section{REFERENCE}

1) AgusSartono. 2012. Financial Management Theory and Applications. BPFE, Jakarta.

2) Baridwan. 2013. Investment Analysis and Portfolio Management. Edition 1. Kanisius, Yogyakarta.

3) Dendawijaya, Lukman. 2012. Banking Management. Second printing. Indonesian Ghalia. Jakarta.

4) Fahmi, I. 2013. In Introduction to Financial Management. Alphabeta, Bandung.

5) Fahmi, Irfan. 2016. Financial Statement Analysis. Fourth printing. Alphabeta, Bandung.

6) Ghozali, Imam. 2011. "Application of Multivariate Analysis With SPSS Program". Publishing Agency Diponegoro University, Yogyakarta.

7) Ghozali. 2016. Application of Multivariete Analysis With IBM SPSS Program. Diponegoro University Publishing Agency, Semarang.

8) Ghozali, Imam. 2018. Application of Multivariete Analysis With IBM SPSS 23 Program (8th Edition). VIII Printing. Diponegoro University Publishing Agency, Semarang.

9) Hasibuan, Syahyunan. 2015. Financial Management 1. USU press. Field.

10) Henry. 2015. Analysis of Financial Statements. Edition 2. Center For Academic Publishing Service, Yogyakarta. 
The Effect of Capital Adequacy Rasio (Car) and Liquidity on Profitability of Islamic Comercial Banks in Indonesia for The 2015-2019 Period

11) Ishmael. 2011. Islamic Banking. Kencana, Jakarta.

12) Kasmir, 2010, "Financial Statement Analysis", Second printing. King GrafindoPersada. Jakarta.

13) Kasmir, 2011, "Financial Statement Analysis", Third printing. King GrafindoPersada. Jakarta.

14) Kasmir, 2014. Analysis of Financial Statements. Seventh edition. PT Raja GrafindoPersada, Jakarta.

15) Kasmir, 2015. Analysis of Financial Statements. Eighth print. PT Raja GrafindoPersada, Jakarta.

16) cashmere. 2016. Financial Statement Analysis. Tenth printing. PT. Raja GrafindoPersada, Jakarta.

17) cashmere. 2017. Analysis of Financial Statements. Eleventh print. PT. Raja GrafindoPersada, Jakarta.

18) K.R. Subramanyam and John J. Wild (2010). Financial Statement Analysis, Ten Edition, SalembaEmpat, Jakarta.

19) Mia LasmiWardiah. 2013. Fundamentals of Banking. Faithful Library. Bandung.

20) Prihadi, T. 2015. Analysis of Financial Statements Theory and Applications. PPM. Seventh Edition. Yogyakarta: UPP STIM YKPN. Jakarta.

21) Priyanto. 2014. Financial Management Based on Balanced Scorecard Approach Theory, Cases, and Business Research. Second printing. Earth Literacy, Jakarta.

22) Santiriana. 2017. Smart Guide to Investing. PT Elex Media Kopotindo, Jakarta.

23) Susilo. 2010. Financial Management Edition 8. Erlangga. Jakarta.

24) SuharsimiArikunto. 2010. Research Procedures A Practical Approach. PT. RinekaCipta. Jakarta.

25) Sugiyono. 2012. Qualitative Quantitative Research Methods and R\&D. Alphabeta, Bandung.

26) Sugiyono. 2013. Qualitative Quantitative Research Methods and R\&D. Alphabeta, Bandung.

27) Sugiyono. 2015. Quantitative Qualitative Research Methods R\&B. Aflabeta, Bandung.

28) Sugiyono. 2017. Qualitative Research Methods: For research that is: exploratory, enterpretive, interactive, and constructive. Alphabeta, Bandung.

29) Syahrial, Dermawan and DjahotmanPurba. 2013. Analysis of Financial Statements. Media Discourse Partners, Jakarta.

30) Law No. 21 of 2008, concerning Islamic Banking, Article 1 point 23. Article 1 paragraph 13.

31) Law No. 10 of 1998 concerning amendments to Law no. 7 of 1992 concerning Banking.

Journal

1) Herman Supardi, H. Suratno, Suyanto. 2016. Effect of Current Ratio, Debt To Asset Ratio,

2) Total Asset Turnover and Inflation on Return On Assets. JIAFE (Scientific Journal of Accounting, Faculty of Economics), Volume 2 No. 2 of 2016, p. 16-27.

3) Dwi Indah Putrianingsih, AriefYulianto. 2016. The Effect of Non Performing Loans (NPL) and Capital Adequacy Ratio (CAR) on Profitability. Management Analysis Journal, Volume 5 No. 2.

4) SyifaMutiaulfah. 2018. The Effect of Current Ratio (CR) and Capital Adequacy Ratio (CAR) on Return On Assets (ROA) at Bank BNI SyariahTbk Period 2014-2016. Thesis, SunanGunungDjati State Islamic University. Bandung

5) DidikGunawan, SaparuddinSiregar, IsnainiHarahap. (2019) conducted a study entitled The Effect Of Car, Nom, ProfitLoss Sharing Financing And Liquidity On Profitability In Islamic Commercial Banks And Islamic Business Units In Indonesia. Procceding International Seminar on Islamic Studies Volume 1, Number 1, Year 2019. 